\title{
PSEUDOMORPHIC CHARACTERS IN V. HUGO'S NOVEL «THE MAN WHO LAUGHS» THROUGH THE CONTEXT OF LITERARY TRADITION
}

\section{Nickolova A. A.}

\section{INTRODUCTION}

It is not always that something we see and its real essence form a harmonic unity: the ugly can hide itself behind beauty, insignificant behind important, complicated - behind plain... Artists always paid attention to numerous reflections of these contradictions and showed them in their own works according to the tendencies of the period of time: in keeping with the medieval worldview of opposition to physical and spiritual, «life is a dream» baroque conception, inconsistencies of romantic dualism, the idea of illusiveness of material and «masquerade» as the universal way of being, the postmodernist theory of «total simulation», etc.

Among expressive means, used to represent a particular phenomenon in different national literature, more attention should be given to pseudomorphic characters (from Greek «pseudo» - «lie», «fiction», «mistake» ${ }^{1}$ та «morpho» $-\left\langle\right.$ form» $\left.{ }^{2}\right)$ : their main common feature is the efficient contradiction between «the essence and its formal presentation/reception, which starts to correlate to the opposing

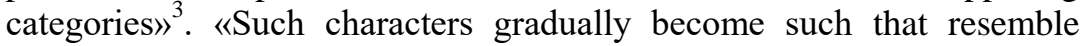
someone else, impersonate others, and are not taken adequately (as a result of metamorphoses, travesty, verbal positional pretence, situational inconformity)» ${ }^{4}$.

${ }^{1}$ Словник іншомовних слів / за ред. О. С. Мельничука. Київ : Українська радянська енциклопедія (УРЕ), 1974. С. 557.

${ }^{2}$ Словник іншомовних слів / за ред. О. С. Мельничука. Київ : Українська радянська енциклопедія (УРЕ), 1974. С. 449.

3 Ніколова О. О. Псевдоморфні персонажі української та російської літератур кінця XVIII - I половини XIX ст. (у контексті європейської традиції): монографія. Запоріжжя : Запорізький національний університет, 2017. С. 5.

4 Ніколова О. О. Псевдоморфні персонажі української та російської літератур кінця XVIII - I половини XIX ст. (у контексті європейської традиції): монографія. Запоріжжя : Запорізький національний університет, 2017. 5. 
The investigation of the features, which provide the «popularity» of pseudomorphic characters in folklore and literature, problems of their possible origin, the ways of their spread in different national cultures, connection with particular genre forms of comic and adventurously fantastic discourses, «wandering» motives, plots, and the principles of typological classification are described in the monograph Psevdomorfni personazhi ukrainskoi ta rosiiskoi literatur kintsia XVIII - I polovyny XIX st. (u konteksti yevropeiskoi tradytsii): monohrafiia [Pseudomorphic characters of Ukrainian and Russian literature of the end of the XVIII- first half of the XIX century (in the context of the European tradition]. Invariants and variants of such characters are taken as the subject of this research.

Important and interesting target of native comparative studies of the $21 \mathrm{st}$ century is to investigate not only «eternal theme» «of inconsistences between genuine and apparently-receptive» ${ }^{5}$ in general, but also certain pseudomorphic characters in different cultural contexts to determine sufficient typological similarities and contact-genetic relations, national historical specificity of interpretation and transformation of this material. Thus, in particular, the novels by V. Hugo are most appropriate for this research.

Creative work of the French writer drew attention of literature scholars many times. For example, V. Romanets, appealing to the studies of different researchers (M. Podolynsky, V. Shurat, I. Zhuravsky, O. Modestova, D. Nalyvayko, I. Lozynsky, M. Moskalenko, R. Bigansky, etc.), correctly notes, that at the current stage of development of Ukrainian national science and culture, exploring and translating Hugo's novels is the necessary element of the general cultural process of modern and following generations' intellectual and spiritual growth» ${ }^{6}$.

However, despite the variety of works on this theme, many issues are tackled insufficiently. The relevance of the study is caused by the necessity to fill the existing lacuna in order to open the new perspectives of understanding the novel «The Man Who Laughs» by V. Hugo from the point of view of the achievements of the modern comparative

5 Ніколова О. О. Псевдоморфні персонажі української та російської літератур кінця XVIII - I половини XIX ст. (у контексті європейської традиції): монографія. Запоріжжя : Запорізький національний університет, 2017. С. 5.

${ }^{6}$ Романець В. М. Творчість В. Гюго в оцінках та перекладах українських митців. URL : file://C:/Users/User/Downloads/Npkpnu_fil_2015_39_53\%20(3).pdf. (Дата звернення: 29.01.2020) 
studies - interpretation of the novel in the broad context of the «eternal» theme of dissonance between the things we see and their real essence, connected with the usage of narrative cliches, based on deception, pretence and irrecognition.

The purpose of the article is to distinguish and characterize pseudomorphic characters in V. Hugo's novel «The Man Who Laughs», and «wandering» motives in the broad cultural context, related to them.

\section{The image of Ursus as a pseudomorphic character in the context of literary tradition}

Outlining the perspectives of further scientific researches, connected with the studying of peculiarities of pseudomorphic characters' functioning, it was also pointed out the reasonableness of searching the material beyond the boundaries, described in the monograph, in particular, «as a result of deep exposure into artistic world of particular writers ${ }^{7}$ and expanding the contextual limits.

«In the light of current ideas, related to the awareness of the significant role of globalization trends in the modern world, the interest of specialists in different humanities and philology to widely contextual researches particularly, is quite clear: such comparative studies drew attention to those art phenomena, which allow to attest the existence of universal value coordinates, worldview orienting points, ideas and use of similar expressive means (images, plots, motives, compositional and stylistic techniques within the same genre forms), and the specifics of transformation the last ones»» ${ }^{8}$.

The article is an attempt to investigate pseudomorphic characters in the novel of the famous French romantic V. Hugo - «The Man Who Laughs»: the employment of specially designed theoreticometodological means concerning contextual analysis, provides the possibility to look at the work from a different perspective, from the point of view of its correlation with the big variety of texts of different national literatures.

Such approach highlights «the existence of universal value coordinates, worldview orienting points, ideas and use of similar

7 Ніколова О. О. Псевдоморфні персонажі української та російської літератур кінця XVIII - I половини XIX ст. (у контексті європейської традиції): монографія. Запоріжжя : Запорізький національний університет, 2017. С. 387.

8 Ніколова О. О. Псевдоморфні персонажі української та російської літератур кінця XVIII - I половини XIX ст. (у контексті європейської традиції): монографія. Запоріжжя : Запорізький національний університет, 2017. С. 134. 
expressive means (images, plots, motives, compositional and stylistic techniques within resembling genre forms), and, also, the specifics of their transformation» ${ }^{9}$.

«The Man Who Laughs» (1869 p.) is a novel, the actions in which take place in the end of the 17th - at the beginning of the 18th centuries in England. However, not all scientists consider it being a historical novel. Thus, A. Belsky doubts this statement, and V. Romanets agrees with him: "As a matter of fact, «The Man Who Laughs» is a social novel, despite it was written basing on past. It is shown through the conflict of the novel by Hugo. This conflict does not correlate with any historical facts, which may be a turning point in the life of a country and are characteristic for this period; but it embodies the contrast between upper and lower classes of English society, social contradictions, about which Gwynplaine speaks so passionately, accusing English peers on behalf of the ordinary people. In this case the social novel about past could not become historical (it has other principles of plot and composition, and other peculiarities of genre, as well). But the last does not lessen the importance of Hugo's novel» ${ }^{10}$.

Moreover, despite the exact historical chronotope of the novel, by means of specific plot situations and images of characters, which cause to the conscious recipient significant associations with different works of world culture, open broad perspectives for comparative studies behind these limits and caused by them unexpected - timeless - interpretations. Not only to the social problematics of «The Man Who Laughs», but also to «eternal» ideas of the novel, scientists should pay attention.

First of all, it is concerned with the realization of the idea of form's illusiveness, which is intended not to reflect the essence, but, first of all, to hide it from people's eyes, distorting the perception of reality.

«Everything is not as it seems» - the idea, approved in the Victor Hugo's novel by means of different expressive means, among which much attention should be given to, of course, sad romantic grotesque, based on the mixture of contrasts.

Taking into consideration the theoretical basis of grotesque, suggested by the French romantic in his preface to the play «Cromwell», the writer, indeed, was aware of the functional potential of this

9 Ніколова О. О. Псевдоморфні персонажі української та російської літератур кінця XVIII - I половини XIX ст. (у контексті європейської традиції): монографія. Запоріжжя : Запорізький національний університет, 2017. С. 134.

10 Романець В. М. Роман про минуле та історичний роман в творчості В. Гюго. Філологічні науки. 2014. Вип. 36. С. 218. 
expressive means, better than others revealing romantic worldview with its basic antinomies, among which the contrast between «the things we see» and «their real essence» play prominent role.

A lot of characters of V. Hugo are grotesque, but not all of them are pseudomorphic, as grotesque can be caused by synthesis of contradictions, which do not have the semantics of pretence, irreality, and so they do not belong to the scope of pseudomprpy.

«Thus, in particular, in this case precedents of contradicting contaminations of formal (animal-anthropic chimeras), meaningful (tragically comic protagonists) or even formally meaningful (ugly and at the same time beautiful characters with externally internal disharmony) features are important» ${ }^{11}$.

So, in the scope of the study are only those grotesque images, which base on artificially created dissonance of semantic and received formally (made by a person, not naturally).

(Such characters are pseudomorphic in the result of their own actions (they pretend being not who they really are), or influence of others (substitution, in purpose to hide the real status of character, create the illusion that he belongs to «alien world»).

In the first case Ursus, Lady Josiana and Lord David Dirry-Mour are taken into account, in the second - Gwynplaine.

Grotesque and pseudomorphy of Ursus is caused by contradiction between his essence (wise, kind person) and the «mask» he was hiding behind (simpleton and misanthrope). It is noteworthy, that pseudomorphy appears not only because of pretence of the «bear», but, first of all, - ostentatious ignorance, specific «innocence» of ironic narrator, who seems does not understand the inner world of this character.

Having extraordinary knowledge and high level of intelligence, Ursus has to indulge unpretentious stupid crowd, to survive in the reality of that time: well-educated person has to become like an ordinary mountebank.

«Ursus was sagacious, contradictory, odd, and inclined to the singular expositions which we term fables. He had the appearance of believing in them, and this impudence was a part of his humour. He read people's hands, Opened books at random and drew conclusions, told fortunes, taught that it is perilous to meet a black mare, still more perilous, as you

11 Ніколова О. О. Псевдоморфні персонажі української та російської літератур кінця XVIII - I половини XIX ст. (у контексті європейської традиції): монографія. Запоріжжя : Запорізький національний університет, 2017. С. 28. 
start for a journey, to hear yourself accosted by one who knows not whither you are going; and he called himself a «dealer in superstitions» ${ }^{12}$.

«The fact is, Ursus was a bit of a savant, a man of taste, and an old Latin poet. He was learned in two forms; he Hippocratised and he Pindarised. He could have vied in bombast with Rapin and Vida. He could have composed Jesuit tragedies in a style not less triumphant than that of Father Bouhours. It followed from his familiarity with the venerable rhythms and metres of the ancients, that he had peculiar figures of speech, and a whole family of classical metaphors» ${ }^{13}$.

In this aspect, Ursus' pseudomorphy appears as a result of temporal, only formal, as it seems, shift from one side of antinomy "wisdom stupidity» to another, opposite, because «the variability and universality of pseudomorphic characters is determined precisely by the correlation of their essence and its presentation/perception with the elements of universal oppositions, inherent in the human worldview (in the case this contradiction is not radical, meaningful and formal inconsistency is absent and the point is in partial disharmony and not pseudomorphy)» ${ }^{14}$.

In the context of literature tradition, on the level of typological similarities, the image of Ursus organically correlates with other pseudomorphic characters, which can be formally reduced to a single invariant - «pseudo-fool» (a clever man in the mask of silly, juggler, psycho) ${ }^{15}$.

«The image of pseudo-buffoon is typical for nationwide folklore tradition... In European artistic works such phenomenon is realized in the grotesque images of wise fools or madmen (Shakespeare's king Lear and Hamlet, Servantes' Don Quixote, Abbot Faria of «The Count of Monte Cristo» by A. Dumas, etc» ${ }^{16}$.

12 Гюго В. Людина, що сміється. URL : http://chtyvo.org.ua/authors/ Hugo_Victor/Liudyna_scho_smiietsia/. (Дата звернення: 29.01.2020).

13 Гюго В. Людина, що сміється. URL : http://chtyvo.org.ua/authors/ Hugo_Victor/Liudyna_scho_smiietsia/. (Дата звернення: 29.01.2020).

14 Ніколова О. О. Псевдоморфні персонажі української та російської літератур кінця XVIII - I половини XIX ст. (у контексті європейської традиції): монографія. Запоріжжя : Запорізький національний університет, 2017. С. 46.

15 Ніколова О. О. Псевдоморфні персонажі української та російської літератур кінця XVIII - I половини XIX ст. (у контексті європейської традиціі): монографія. Запоріжжя : Запорізький національний університет, 2017. С. С. 71.

16 Ніколова О. О. Псевдоморфні персонажі української та російської літератур кінця XVIII - I половини XIX ст. (у контексті європейської традиції): монографія. Запоріжжя : Запорізький національний університет, 2017. С. С. 72. 
Pseudo-fool has to hide from others his intellectual potential, which exceeds intelligence of the most (or everybody) around him. The reasons for this pretence can be different, but in most cases such behavior is caused by security considerations (who will take a fool seriously?) or awareness of futility of demonstrating his own ideas, views to a crowd which, in principle, is not capable to understand them. Pseudo-fool is forced to accept the offered «rules of the game», to avoid problems, or, even, death. Ursus choses this very way.

If a wise fool expresses his thoughts and ideas directly, there is a risk of being laughed at and considered being psycho. In this very situation gets Gwynplaine, the character of Hugo's novel (see the third chapter of the article).

In another perspective, contrasting the form and essence of Ursus on the level of antinomy «kindness - evil», which is accumulated in the concepts of «philanthropy» and «misanthropy», is important.

«Never did the wolf bite: the man did now and then. At least, to bite was the intent of Ursus. He was a misanthrope, and to italicise his misanthropy he had made himself a juggler» ${ }^{17}$. "His great business was to hate the human race. He was implacable in that hate. He put lame cripples on their legs again, and hurled this sarcasm at them, «There, you are on your paws once more, may you walk along in this valley of tears!» When he saw a poor man dying of hunger, he gave him all the pence he had about him, growling out, «Live on, you wretch! eat! last a long time! It is not I who would shorten your penal servitude». After which, he would rub his hands and say, «I do men all the harm I can» ${ }^{18}$.

The wandering philosopher, who gives the last money to other children (Gwynplaine, Dea), risking starving to death, brings them up as his own, protecting them from hostile society, at the same time tries to act as a rude, cruel hermit. Ursus tells Gwynplaine and Dea unpleasant things on purpose, always scolds them, but all these he does only for their best, their safety. As a matter of fact, the philosopher sincerely wishes the lovers happiness.

In this aspect, Ursus also looks like a holy fool (typological parallel): his speech of an inveterate misanthrope is a specific form of selfabasement and, at the same time, of ironic self-defense on the one hand,

17 Hugo V. The Man who laughs. URL : http://chtyvo.org.ua/authors/ Hugo_Victor/Liudyna_scho_smiietsia/.(accessed: 29.01.2020).

Hugo V. The Man who laughs. URL : http://chtyvo.org.ua/authors/ Hugo_Victor/Liudyna_scho_smiietsia/.(accessed: 29.01.2020). 
and challenge to the world, pseudo-value and absurdity of which the philosopher is quite aware of, - on the other hand.

Therefore, in this case the means of creating pseudomorphy is a verbally positional pretence when «a character with the help of untrue words and behavior tries to be someone else he not really is (to demonstrate not characteristic for him intelligence, moral qualities, or vice versa, to hide them, to create the impression of his own significance or insignificance, etc) $)>$.

Pseudomorphy of Ursus is determined by essential functional contradictions on the level of antinomies «wisdom - stupidity», «kindness - evil».

\section{Lady Josiana and Lord David as pseudomorphic characters in the context of literary tradition}

Lady Josiana and Lord David are on the opposite side in the novel by French romantic: they are aristocrats, the masters of England, which have all material goods and pleasures, unlike Ursus.

But they, as well as the poor philosopher, despise norms and rules of the world. That's why they choose one of the main forms of revolt against them (in order to establish their own superiority over others), pretence - the game with disguising as someone to go beyond «decency». Ursus' simulation is caused by conditions he cannot change (ignorance of society, social injustice), masquerade of aristocrats - is just a fun, rescue from boredom, looking for new thrilling feelings.

«Dressing up as someone (changing clothes, masking), usually has the aim to change visually gender or social status...: in the first case a girl/woman disguises in man's attire, or vice versa, a man puts on a woman's dress, and in the second case - change of clothes shows formal transfer of a person to another social group, class (especially, when a wealthy person pretends being a poor, a mountebank tries to cheat on somebody by means of an expensive suit, etc» ${ }^{20}$.

Pseudomorphy of these two characters is not permanent: they transform into other people only for a certain period of time, by means of travesty. Such masquerade of the rich, satiated with life, causes certain

19 Ніколова О. О. Псевдоморфні персонажі української та російської літератур кінця XVIII - I половини XIX ст. (у контексті європейської традиції): монографія. Запоріжжя : Запорізький національний університет, 2017. С. 24.

20 Ніколова О. О. Псевдоморфні персонажі української та російської літератур кінця XVIII - I половини XIX ст. (у контексті європейської традиції): монографія. Запоріжжя : Запорізький національний університет, 2017. С. 23. 
associations and stimulates to specify the typological coincidence with other works of world literature.

As for Lord David, he likes to play the role of a commoner, a sailor Tom-Jim-Jack: in such image he visits fist fights, takes part in local poor people's entertainment.

«The true noble is he who smacks of the people. Therefore, it was that Lord David frequented the taverns and low haunts of London and the Cinque Ports. In order to be able at need, and without compromising his rank in the white squadron, to be cheek-by-jowl with a topman or a caulker, he used to wear a sailor's jacket when he went into the slums. This gave him great freedom of action. The low people whom Lord David used to meet in the stews, and with whom he mixed, held him in high esteem, without ever dreaming that lie was a lord. They called him Tom-Jim-Jack» ${ }^{21}$.

Lord David's pseudomorphy and grotesque base on the essence formal contradiction «upper - low» in the aspect of social importance: being an aristocrat (the «upper» class of society), he plays the role of a commoner («low» class).

In this case, he typologically resembles pseudomorhic characters, united on the level of generalization in the invariant type of «pauperprince»: «rich/powerful character (often a ruler) who pretends being another person (poor, humiliated) or is taken as such. This invariant functions in plots, based on numerous repeated motives, typical for certain genre traditions» ${ }^{22}$.

The range of such motives is quite broad: «a ruler/noble person travels incognito» (numerous folklore legends, ballads, historical novel «Ivanhoe» by V. Scott, «The Oriental Tale» by I. Krylov «Kaib», fiabas by C. Gozzi «The Stag King» and «The Fortunate Beggars», fairytale «The Adventures of Said» by W. Hauff, «Decameron» by G. Boccaccio, etc), «the master and his servant change their clothes and roles» (for saving the master - «The Prisoners» by Plautus, «Ivanhoe» by V. Scott, for testing the fiancée - «The Affected Young Ladies» by Molière, «The Game of Love and Chance» P. C. de Chamblain de Marivaux, «Master

21 Гюго В. Людина, що сміється. URL : http://chtyvo.org.ua/authors/ Hugo_Victor/Liudyna_scho_smiietsia/.(Дата звернення: 29.01.2020).

${ }_{22}$ Ніколова О. О. Псевдоморфні персонажі української та російської літератур кінця XVIII - I половини XIX ст. (у контексті європейської традиції): монографія. Запоріжжя : Запорізький національний університет, 2017. С. 52. 
Servant» by P. de Rojas, «Jodelet, or the Master Servant» by P. Scarron, etc» ${ }^{23}$.

A widely spread cliché «a rich person plays a role of a commoner for entertainment» allows to find parallels between V. Hudgo's novel and other works of world culture treasury (tales from the collection «A Thousand and One Nights» novel «The Comical History of Francion» by Ch. Sorel, short story «The Squire's Daughter» by A. Pushkin, etc).

From a diachronic perspective of contextual analysis, we can also see similarities between lord David and Dorian Gray («The Picture of Dorian Gray» by O. Wilde). Dorian Gray pretends to be a commoner to enjoy new feelings in poor blocks of London and to smoke opium in sordid dens. The widespread in world literature technique of creating intrigue, making the plot more dynamic, beside all this intensifies the emotional tension, caused by gradation of Dorian's crimes. Temporal formal integration in the society of outcasts is the evidence that he despises all the excepted norms: exceeding the social limits in life is reflected in ruining morality in his consciousness. In this case the associations with Lord David, the character from Hugo's novel, appear... For a depraved aristocrat such masquerade is just a way to entertain himself, to thrill, to get unusual impressions and, at the same time, - to express contempt to commonly accepted rules. Therefore, such motive in both novels is a vivid means to characterize the image of character ${ }^{24}$.

Special attention should be given to the image of Lady Josiana: made completely on the crossing of contradictions, it is a vivid example of romantic grotesque.

«No love, even no purity... To appear yielding, and to be unapproachable, is perfection... A splendid bosom, heaving harmoniously over a royal heart, a glance full of life and light, a countenance pure and haughty, and who knows? Below the surface was there not, in a semi-transparent and misty depth, an undulating,

23 Ніколова О. О. Псевдоморфні персонажі української та російської літератур кінця XVIII - I половини XIX ст. (у контексті європейської традиції): монографія. Запоріжжя : Запорізький національний університет, 2017. С. 55.

24 Ніколова О. О., Веремчук Е. О. Специфіка псевдоморфних персонажів епічних творів O. Вайльда на тлі літературної традиції. URL : http://www.vestnik-philology.mgu.od.ua/archive/v39/part_1/28.pdf. Дата звернення: 29.01.2020). 
supernatural prolongation, perchance deformed and dragon-like--a proud virtue ending in vice in the depths of dreams» ${ }^{25}$.

The beautiful aristocrat is bored and resorts to travesty to have a chance observe men's fun - she puts on man's suit. "One evening in winter there was in a meadow there, the gates of which were locked, a fight, at which Josiana, escorted by Lord David, was present. Lady Josiana made only this concession to propriety--she dressed as a man, a very common custom at that period» ${ }^{26}$.

The motive «a girl puts on man's attire» appears in many works of world folklore and literature: in this case, pseudomorphy is created through contravention of formal essential correspondence within antinomy «male-female».

Exploring the works on the research of functioning of this motive, the leading tendencies of its artistic usage - is provided through the monography Psevdomorfni personazhi ukrainskoi ta rosiiskoi literatur kintsia XVIII - I polovyny XIX st. (u konteksti yevropeiskoi tradytsii): monohrafiia [Pseudomorphic characters of Ukrainian and Russian literature of the end of the XVIII - first half of the XIX century (in the context of the European tradition $]^{27}$.

In particular, there was mentioned that literary life of different motives with changing male-female clothes (and vice versa) finds its realization also in novelistics (the third and the ninth stories of the second day in «Decameron» by G. Boccaccio, «The Novel of How the Revelation Source Was Found» by A. de Eslavo, «Pastimes and Merry Tales» by B. des Périers, «Pacheko and Palomeke» by G. de Céspedes y Meneses, «Tales» by Juan de Timoneda, «Adventures of Diana» by Lope de Vega, etc), drama («Ruffian Castrucho» by Lope de Vega, «White Hands don't Offend» and «Life is a Dream» by P. Calderón, «Don Gil of the Green Breeches» by T. Molina, «The Servant of Two Masters» by

25 Гюго В. Людина, що сміється. URL : http://chtyvo.org.ua/authors/ Hugo_Victor/Liudyna_scho_smiietsia/. (Дата звернення: 29.01.2020).

26 Гюго В. Людина, що сміється. URL : http://chtyvo.org.ua/authors/ Hugo_Victor/Liudyna_scho_smiietsia/. (Дата звернення: 29.01.2020).

27 Ніколова О. О. Псевдоморфні персонажі української та російської літератур кінця XVIII - I половини XIX ст. (у контексті європейської традиції): монографія. Запоріжжя : Запорізький національний університет, 2017. 450 с. 
C. Goldoni, «The Merchant of Venice», «The Two Gentlemen of Verona», «Twelfth Night», «As You Like It» by W. Shakespeare, etc» ${ }^{28}$.

The main difference in the realization of this motive in V. Hugo's novel is that while for most characters cross-dressing in man's attire is a specific sacrifice (often - for a man) or is caused by necessity (difficult life situation, need to realize the potential in patriarchal society, etc.), for Lady Josiana, it's just fun and nothing more.

Therefore, Lady Josiana and Lord David's pseudomorphy is caused by essential formal inconsistencies within antinomies «upper - low» (in the social aspect) and «male - female», which appear as a result of travesty in certain situations.

\section{Pseudomorphy of Gwynplaine in the context of literary tradition}

In the novel by Victor Hugo, Gwynplaine plays a very important role: the grotesque of his image is formed, first of all, by means of contamination of contradictions «beautiful» - «ugly» (his deformed appearance and beautiful inner world) and «high»- «low» in social aspect (being an English lord, he has to live as a poor buffoon). Due to the last inconsistency, we can consider him being a pseudomorphic character.

Gwynplaine is pseudomorphic not by his fault: neither he, nor people around him know, who this young crippled man is. Lord Clancharlie's heir all his life is considered being a juggler. «That child is Lord Fermain Clancharlie, the only legitimate son of Lord Linnaus Clancharlie... That child was brought up and trained to be a mountebank at markets and fairs» ${ }^{29}$.

The discovery of the mystery of Gwynplaine's parentage is a real wonder, it resembles the awakening from dream, causing an association with the play «Life is a Dream» by P. Calderón.

«Yes,» he said, «I have come to awaken you. For twenty-five years you have slept. You have been dreaming. It is time to awake. You believe yourself to be Gwynplaine; you are Clancharlie. You believe yourself to be one of the people; you belong to the peerage. You believe yourself to be of the lowest rank; you are of the highest. You believe yourself a player; you are a senator. You believe yourself poor; you are

28 Ніколова О. О. Псевдоморфні персонажі української та російської літератур кінця XVIII - I половини XIX ст. (у контексті європейської традиції): монографія. Запоріжжя : Запорізький національний університет, 2017. 450 с. 63.

29 Гюго В. Людина, що сміється. URL : http://chtyvo.org.ua/authors/ Hugo_Victor/Liudyna_scho_smiietsia/.(Дата звернення: 29.01.2020). 
wealthy. You believe yourself to be of no account; you are important. Awake, my lord!» ${ }^{30}$.

V. Hugo's novel is associated not only with the Spanish baroque play, but also with other works of world literature by means of traditional motive of bringing up a descendant of the rich by foster poor parents (as a result of kidnapping, replacement, attempt to get rid of unwished heir, hide some noble woman's pregnancy, etc: «Daphnis and Chloe» by Longus, «Aethiopica» by Heliodorus, the sixth novel of the sixth day in «Decameron» G. Boccaccio, «The Illustrious Kitchen-Maid» and «The Gypsy Girl» by Miguel de Cervantes, «The Green Bird» by C. Gozzi, «The Life of Marianne» by P. C. de Chamblain de Marivaux, «Das Käthchen von Heilbronn» by H. von Kleist ... etc» ${ }^{31}$.

But, if in all mentioned before literary works this motive not only helped to create intrigue and but provided «happy end» («the establishment of justice solves all problems $\left.{ }^{32} \gg\right)$, in Hugo's novel - vice versa: the discovery of character's noble parentage results in tragedy (further Dea and Gwynplaine's death).

By transforming the traditional material so dramatically, the French writer reveals the cruelty of world, rejecting the possibility of victory of good over evil, like in fairytales.

Special attention should be given to the episode with Gwynplaine's speech in the Parliament, when he talks about defending poor people, hoping sincerely to arouse the sympathy of the lords, strike them with the terrible truth. Everything, that the Clancharlie's heir says, testifies the intelligence of ex-comedian, mastery of the word, ability to see the point, and make conclusions. Such oratorical gift of the speaker, who lacks education, seems a little bit improbable. Of course, if not taking into account the fact that he was brought up by Ursus - the sage and philosopher.

Through Gwynplaine V. Hugo expresses his ideas, his thoughts about the problem of social injustice. In fact, Gwynplaine is shown as a personality, who is much higher intellectually than other lords.

30 Гюго В. Людина, що сміється. URL : http://chtyvo.org.ua/authors/ Hugo_Victor/Liudyna_scho_smiietsia/.(Дата звернення: 29.01.2020).

${ }^{31}$ Ніколова О. О. Псевдоморфні персонажі української та російської літератур кінця XVIII - I половини XIX ст. (у контексті європейської традиції): монографія. Запоріжжя : Запорізький національний університет, 2017. С. 56.

32 Ніколова О. О. Псевдоморфні персонажі української та російської літератур кінця XVIII - I половини XIX ст. (у контексті європейської традиції): монографія. Запоріжжя : Запорізький національний університет, 2017. С. 56. 
«My lords, you are highly placed... But there is something below you--above you, it may be. My lords, I bring you news; news of the existence of mankind...

Oh! I conjure you, have pity. Pity for whom? Pity for yourselves. Who is in danger? Yourselves! Do you not see that you are in a balance, and that there is in one scale your power, and in the other your responsibility! It is God who is weighing you Hearts are all alike. Humanity is nothing but a heart. Between those who oppress and those who are oppressed there is but a difference of place. Your feet tread on the heads of men. The fault is not uours; it is that of the social Babel. The building is faulty, and out of the perpendicular. One floor bears down the other. Listen, and I will tell you what to do. Oh! as you are powerful, be brotherly. As you are great, be tender... Have pity! yes, have pity on yourselves; for the people is in its agony, and when the lower part of the trunk dies, the higher parts die too. Death spares no limb. When night comes no one can keep his corner of daylight. Are you selfish; then save others. The destruction of the vessel can not be a matter of indifference to any passenger. There can be no wreck for some that is not wreck for all. Oh! believe it, the abyss yawns for all! ${ }^{33}$.

But the glorious speech of a true sage and prophet is perceived by the lords absolutely not in the way as Gwynplaine expects: they begin to laugh at him, mock him, because in the public eye - he is a freak, a cripple, a worthless creature. The wisest of all is declared to be a fool, a madman, a buffoon.

In this aspect Gwynplaine can be considered as a pseudo-fool, similar to a certain extent to Ursus, with the only difference that Ursus chooses this mask for himself, while his foster-child is seen and proclaimed like this by the lords.

Thus, pseudomorphy of Gwynplaine is the result of situational inconformity, which «occurs as a result of a concourse of circumstances, a play of chance, confusion, unrecognizability, replacement made by someone else» ${ }^{34}$, inadequate reception, etc. Essential and formalreceptive inconsistency is caused by contradictions at the level of antinomies «upper - lower» (in the social class aspect) and «wisdom stupidity».

33 Гюго В. Людина, що сміється. URL : http://chtyvo.org.ua/authors/ Hugo_Victor/Liudyna_scho_smiietsia/.(Дата звернення: 29.01.2020).

$34-$ Ніколова О. О. Псевдоморфні персонажі української та російської літератур кінця XVIII - I половини XIX ст. (у контексті європейської традиції): монографія. Запоріжжя : Запорізький національний університет, 2017. С. 24. 
On the one hand, the plot situations with disguise, pretence, irrecognition, replacement, inadequate reception and pseudomorphic characters impart to V. Hugo's novel a tinge of adventurous spirit immanent to romanticism of W. Scott's tradition: «Aiming at the creation of a sharp intrigue in the spirit of W. Scott implies active description of replacement, disguise, status-and-role inconsistencies, and leads to the emergence of various pseuds (pseudomorphic characters O. N.) in works on historical themes (collective synchronous connections on the motivational-compositional level)» ${ }^{35}$.

On the other hand, the corresponding material conforms to the purpose of expressing the author's concept, romantic worldview. After all, as O. Kornienko quite rightly points out, «previously, the Qui pro quo method served mainly for a rising action and as a means of further «complication of the plot», but "with the development of literature, it «significantly expands its functional field on the content and formal levels and becomes a means of characterizing not only individual characters (human types), but also phenomena of a more general plan...» (the objective world, etc. $)^{36}$. This is one of the main functions that pseudomorphic characters perform in the literature of romanticism.

The study of the novel by V. Hugo «The Man Who Laughs» in the chosen aspect demonstrates the possibilities of contextual analysis and confirms the presence of various typological parallels with numerous works of world literature (mainly at the level of «wandering» motives, closely related to pseudomorphic characters).

As O. Freidenberg points out, «the motive is a common image, and we should not follow the «similarity», but the unity of images, without fear of diversity of motive designations. The same image can give motives different in appearance, but absolutely identical internally: the Devil and the Angel, Abel and Cain are the two brothers that come from one father ${ }^{37}$. The scientist proves that contextual analysis opens wide horizons for the research in this direction. «The issue of the degree of consciousness in the choice and disguise of a particular plot, a certain

35 Ніколова О. О. Псевдоморфні персонажі української та російської літератур кінця XVIII - I половини XIX ст. (у контексті європейської традиції): монографія. Запоріжжя : Запорізький національний університет, 2017. С. 329.

36 Корниенко О. А. Типология форм игровой поэтики в литературе. Актуальні проблеми слов'янської філологї. Серія: Лінгвістика і літературознавство : міжвуз. зб. наук. ст. 2009. Вип. ХХ. С. 438.

37 Фрейденберг О. М. Методология одного мотива. Tpуды по знаковым системам. 1987. № 20. С. 128. 
motive, ... about similarity and about borrowing - in general it is impossible to solve, if not to plunge into the analysis of the very nature of the plot or motive in question. And for this analysis, it is necessary to take variations of the most diverse works from the most different authors and put all the authorship in isolation, exposing a single plot» ${ }^{38}$.

Exactly this approach allows us to differentiate typological similarities between the images created by the French writer in his novel and characters from other national literatures (in terms of synchrony and diachrony): this is about belonging of these phenomena «to a certain type, a genus. This affiliation is often manifested even when literary facts do not have direct connections with each other» ${ }^{39}$.

At the same time, we overcome the «distance, estrangement between individual cultures and literatures, in search of their structural similarities... In the act of juxtaposition, the time distance is overcome and replaced with syncretic simultaneity. Comparative methodology emphasizes the features of the place and time of historical events, and also emphasizes the repeatability, parallelism and universality of historical situations»» ${ }^{40}$.

The research prospects are determined by the expediency of highlighting the general trends in the functioning of pseudomorphic characters, the motives of pretense/unrecognizability in the novels of V. Hugo in general and in the works of other French romantics.

\section{CONCLUSIONS}

Thus, the images of pseudomorphic characters are actively used by writers of various national literatures to represent the theme of contradictions between the genuine and receptive.

In the analyzed novel by V. Hugo, the romantics' idea of the deceptiveness and illusory nature of many phenomena of life and society is confirmed with the help of grotesque and at the same time pseudomorphic images.

First of all, Ursus (a wise, kind man who hides behind the «mask» of a misanthropic buffoon) and in this aspect he corresponds to the traditional type of «pseudo-fool», the motive of feeble-mindedness: his

38 Фрейденберг О. М. Методология одного мотива. Tpyды nо знаковым системам. 1987. № 20. С. 120.

39 Храпченко М. Б. Типологическое изучение литературы. Собрание сочинений в 4-х томах. Москва : Художественная литература, 1981. Т. 3. С. 263.

40 Будний В. Порівняльне літературознавство : підручник. Київ : Видавничий дім «Києво-Могилянська академія», 2008. С. 343. 
pretense is an ironic and pessimistic «revolt» against the cruel world with its pseudo-values.

Secondly, Lord David, who often disguises himself as a simple sailor Tom-Jim-Jack for fun, and in this aspect he is typologically similar to the type of «pauper-prince» represented in many works of world literature: his travesty is also a kind of defiance (ignoring of social boundaries is associated with disregard for generally accepted norms of behavior).

Thirdly, Gwynplaine - son of Lord Clancharlie, whom everyone consider to be the poor jester: description of his hard fate is associated with P. Calderón's drama «Life Is a Dream», a common plot, which is based on the mystery of the parentage of the character, the upbringing of the son of a rich/noble person by other poor parents (because of theft, the desire to get rid of the unwanted heir): the absence of expected happy denouement contributes to the expression of the tragic worldview of the writer. Sensible speech, which was proclaimed by Gwynplaine in the House of Lords, and his ridicule as a fool, as a juggler gives grounds to compare this character with the image of a pseudo-fool.

Special attention should be paid to the fact that Lady Josiana is dressing up as a man: the «wandering» motive of «the girl dressed in men's clothes» is deprived of its traditional heroic color in the novel by V. Hugo.

The corresponding material also increases the intrigue, contributes to the aggravation of collisions, and gives an adventurous colour to the plot of the novel (in the spirit of the W. Scott's tradition).

\section{SUMMARY}

The study deals with the issue of the varieties and features of pseudomorphic characters in the novel „The Man Who Laughs" by $\mathrm{V}$. Hugo in the broad context of the literary tradition. This article analyzes typical plot situations based on the dissonances of the genuine and visible, which comply with the goal of implementing the author's idea in his work. In the corresponding thematic aspect, we determined the similarity of the grotesque images from the novel by the French artist in words (in particular, Ursus, Lord David Dirry-Moir, Lady Josiana, Gwynplaine) with other characters of European literature.

Special attention is given to the immanent cultural traditions of narrative clichés with cross-dressing (with the aim of visual change of gender or social status - travesty of Lord David and Lady Josiana), verbal pretence (the „mask" of misanthrope and a simpleton, behind which Ursus hides), the replacement (the ,wandering" motive of upbringing of the heir of a noble family by foster poor parents associated 
with the figure of Gwynplaine). There is a strong tendency to develop those aspects, which provide the most of opportunities for figurative reflection of the ideas of romanticism through the creation of pseudomorphic characters. This refers, in particular, to the implementation of the idea of deceptive form, designed not so much to reflect the essence, but to hide it from human eyes, distorting the perception of reality.

This opinion is stated in the novel by V. Hugo „The Man Who Laughs" with the help of various expressive means, among which the dark romantic grotesque, based on a combination of contrasts, deserves special attention. Our studies also prove the promising outlook of pseudomorphic characters as a subject of scientific analysis in general and comparative research in particular, due to the specific character of the phenomenon, which determines its active functioning in the art of different times and countries.

\section{REFERENCES}

1. Будний В. Порівняльне літературознавство : підручник. Київ : Видавничий дім «Києво-Могилянська академія», 2008. 432 с.

2. Гюго В. Людина, що сміється. URL : http://chtyvo.org.ua/ authors/Hugo_Victor/Liudyna_scho_smiietsia/. (Дата звернення: 29.01.2020).

3. Корниенко О.А. Типология форм игровой поэтики в литературе. Актуальні проблеми слов'янської філології. Серія: Лінгвістика і літературознавство : міжвуз. зб. наук. ст. 2009. Вип. ХХ. С. 437-551.

4. Ніколова О. О. Псевдоморфні персонажі української та російської літератур кінця XVIII - I половини XIX ст. (у контексті європейської традиції): монографія. Запоріжжя : Запорізький національний університет, 2017. 450 с.

5. Ніколова О. О., Веремчук Е. О. Специфіка псевдоморфних персонажів епічних творів О. Вайльда на тлі літературної традиції. URL : http://www.vestnik-philology.mgu.od.ua/archive/v39/ part_1/28.pdf. (Дата звернення: 29.01.2020).

6. Романець В. М. Роман про минуле та історичний роман в творчості В. Гюго. Філологічні науки. 2014. Вип. 36. С. 217 - 221.

7. Романець В. М. Творчість В. Гюго в оцінках та перекладах українських митців. URL : file:///C:/Users/User/Downloads/ Npkpnu_fil_2015_39_53\%20(3).pdf. (Дата звернення: 29.01.2020).

8. Словник іншомовних слів / за ред. О. С. Мельничука. Київ : Українська радянська енциклопедія (УРЕ), 1974. 776 с. 
9. Фрейденберг О. М. Методология одного мотива. Tруды по знаковым системам. 1987. № 20. С. $120-130$.

10. Храпченко М. Б. Типологическое изучение литературы. Собрание сочинений в 4-x томах. Москва : Художественная литература, 1981. Т. 3. С. 258-295.

Information about the author:

Nikolova O. O.,

Doctor of Philology, Associate Professor, Professor at the Department of German Philology and Translation, Zaporizhzhia National University 66, Zhukovsky str., Zaporizhzhia, 69600, Ukraine 